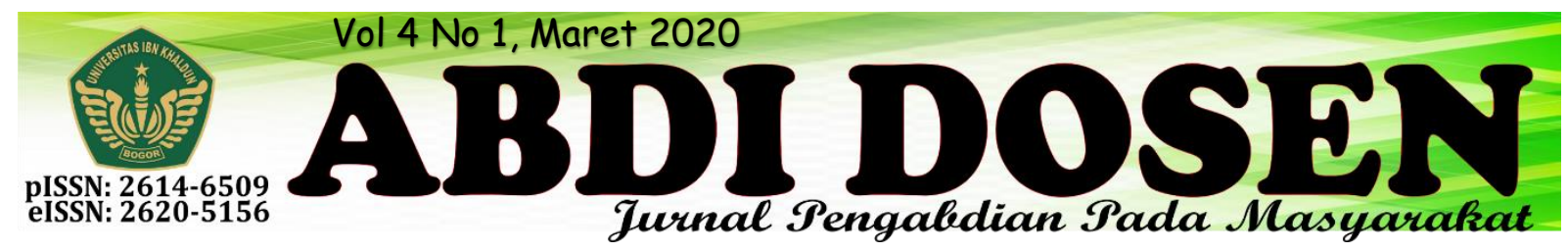

\title{
MEWUJUDKAN MASYARAKAT DESA TEGALLEGA YANG SADAR AKAN PENDIDIKAN DAN KEMANDIRIAN
}

\author{
Leny Muniroh $^{1}$, Gunawan Ikhtiono ${ }^{2}$, Muhamad Fikriansyah ${ }^{3}$ \\ lenny@uika-bogor.ac.id ${ }^{1}$ \\ gunawanikhtiono@gmail.com ${ }^{2}$
}

Dosen Fakultas Ekonomi dan Bisnis ${ }^{1}$, Dosen Fakultas Agama Islam² ${ }^{2}$ Mahasiswa KKN Kelompok $49 \& 50$ Tahun $2019^{3}$

\begin{abstract}
ABSTRAK
Kuliah Kerja Nyata (KKN) merupakan suatu kegiatan pengabdian mahasiswa terhadap masyarakat yang wajib dilaksanakan oleh seluruh mahasiswa yang sudah mulai memasuki semester 7 di Universitas Ibn Khaldun Bogor. Adapun tujuan dari kegiatan KKN adalah melatih mahasiswa untuk belajar mengindetifikasi, mencari alternatif solusi pemecahan masalah yang ada di tengah-tengah masyarakat, selain itu melalui KKN mahasiswa akan mendapatkan pengalaman hidup yang mungkin tidak diperoleh selama kegiatan pembelajaran dibangku kuliah. Pada tanggal 6 Agustus s.d. 6 September 2019 kami telah melaksanakan program Kuliah Kerja Nyata (KKN) di Desa Tegallega. Desa Tegallega adalah salah satu desa yang terletak di Kecamatan Cigudeg, Kabupaten Bogor yang terbentuk atau berdiri sejak tanggal 18 Maret 1984 atas dasar pemekaran dari Desa Batujajar. Dalam progam Kuliah Kerja Nyata (KKN) di Desa Tegallega ini kami telah menjalankan beberapa progam-progam unggulan pada setiap bidang diantaranya pada bidang pendidikan yaitu learn and fun dalam pembelajaran Bahasa Inggris, education competition pada bidang agama, pebuatan plang petunjuk jalan pada bidang teknik, penyuluhan mencuci tangan (PHBS) pada bidang kesehatan, serta Market Day pada bidang ekonomi. Semua program dapat terlaksana dengan baik dan lancar karena terdapat kerjasama yang baik antara semua anggota kelompok KKN 49-50, masyarakat, maupun pihak desa.
\end{abstract}

\section{Kata Kunci : KKN, Progam KKN, Tegallega}

\section{PENDAHULUAN}

Indonesia merupakan Negara kepulauan, diantara ratusan ribu pulau yang dimiliki oleh Indonesia ada lima pulau terbesar di Indonesia yaitu Pulau Sumatera, Jawa, Kalimantan, Sulawesi, dan Papua. Dari kelima pulau tersebut pulau jawa yang sangat padat penduduknya, selain padat penduduk pulau jawa merupakan pulau tersibuk aktifitasnya diantara pulau-pulau lainya. Hampir disemua daerah kota kabupaten di pulau jawa memiliki visi misi untuk mengembangkan keseluruhan daerah agar menjadi daerah yang maju dan mampu mengikuti arus perkembangan jaman, dalam konteks ini tidak terkecuali kabupaten Bogor. Kabupaten bogor adalah kabupaten yang termasuk kedalam provinsi Jawa Barat, Kabupaten Bogor memiliki Visi dan Misi sebagai berikut Kabupaten Bogor Termaju, Nyaman dan berkeadaban. Untuk mewujudkan visi diatas, misi atau upaya-upaya yang akan dilaksanakan adalah : pertama mewujudkan masyarakat yang berkualitas, kedua mewujudkan 
perekonomian daerah yang berdaya saing dan berkelanjutan, ketiga mewujudkan pembangunan daerah yang merata, berkeadilan, dan berkelanjutan, keempat mewujudkan kesalehan social, serta yang terakhir mewujudkan tata kelola pemerintahan daerah yang baik.

Kabupaten Bogor sendiri terdiri dari 40 Kecamatan, salah satunya adalah Kecamatan Cigudeg, Kecamatan Cigudeg memiliki visi Mewujudkan Cigudeg Ngadeg Untuk Mendukung Kabupaten Bogor Termaju Di Indonesia. Kecamatan Cigudeg memiliki 15 Desa salah satu dari Desa di Kecamatan Cigudeg adalah Desa Tegallega.

Lokasi Kuliah Kerja Nyata (KKN) tematik terintegrasi 2019 kelompok 49-50 UIKA Bogor berada di Desa Tegallega. Desa Tegallega merupakan salah satu desa yang terletak pada Kecamatan Cigudeg, Kabupaten Bogor. Desa Tegallega memiliki luas wilayah 961,125 ha, dengan jumlah penduduk sekitar 7,549 jiwa yang terdiri dari 3.998 Laki-laki dan 3.551 perempuan, adapun jumlah Kartu Keluarga Desa Tegallega kurang lebih 1.778 KK. Sedangkan jumlah Keluarga Miskin (Gakin) mencapai 511 K.K dengan persentase $30 \%$ dari jumlah keluarga yang ada di Desa Tegallega. Kepala Desa atau Pejabat Sementara adalah Bapak SUKRIYA (PJS 1984-1986), selajutnya di jabat oleh Bapak SUARDI (1986-1994), dua Periode (1995-2002), dan Bapak GUNAWAN memimpin Dua Periode ( 2003-2008 s.d 2008-2014) dan Sekarang dipimpin oleh Bapak H.Samsu untuk priode 2014-2020, dengan jumlah Dusun 5 (Lima) Rw 10 (Sepuluh) dan Rt 32 (Tiga puluh dua). Berdasarkan data yang kami peroleh dari web Kecamatan Cigudeg pada awal bulan Agustus 2019.
Desa Tegallega memiliki 5 Dusun, dan lokasi posko KKN kelompok 49-50 berada di Dusun Binong, Dusun Binong bukan merupakan dusun yang penduduknya paling banyak di Desa Tegallega, meski bukan dusun dengan jumlah penduduk terbanyak namun penduduk di dusun Binong tergolong cukup padat. Di Dusun Binong Terdapat 3 RT yang ada dibawah naungan Jaro atau Kadus. Masyarakat di Desa Tegallega memang masih menganut Aspek tidak terkecuali masyarakat di Dusun Binong, di dusun ini speker masih dilarang, untuk perempuan dianjurkan untuk menggunakan sarung atau rok, serta batasan antara laki-laki dan perempuan masih sangat terjaga disana. Rata-rata pendidikan masyarakat Dusun Binong tergolong masih memprihatinkan karna sebagian besar masyarakatnya hanya sebatas lulusan sekolah tingkat Sekolah Dasar saja. Untuk mata pencaharian masyarakat Dusun Binong sebagian mereka bekerja sebagai pegawai harian lepas di perusahaan tambang pasir dan batu dekat dusun, sebagian menjadi petani, dan buruh bangunan. Meski prekonomian di Dusun Binong dikatakan kurang baik, namun kesehatan masyarakatnya baik, terbukti dengan anak-anak yang tumbuh dengan baik dan sehat, tidak dijumpai anak yang mengalami gizi buruk, dan tidak pula dijumpai masyarakat yang memiliki penyakit yang mengkhawatirkan. Selain itu respon masyarakat terhadap pendatangpun menyenangkan mereka mampu menyambut kami dengan penuh kehangatan dan keramah tamahan. Pendidikan masyarakat Dusun Binong memang tertinggal dan mereka masih menganut system aspek, namun masyarakat Dusun Binong sangat open minded terhadap ilmu-ilmu baru bahkan mereka terkesan antusias akan ilmu, tidak hayal jika hari pertama kami menetap 
di Dusun Binong banyak anak-anak yang dengan sendirinya dating keposko untuk belajar atau sekedar bermain dan berkenalan dengan kami.

Setelah kami melakukan observasi desa pada tanggal 6-8 Agustus 2019 Desa Tegallega memiliki kondisi sebagai berikut

1. Akses jalan Nasional yang menghubungkan antara kecamatan cigudeg dengan kecamatan rumpin

2. Desa Tegallega memiliki potensi pertambangan yang besar sehingga menarik para pengusaha tambang untuk mendirikan perusahaan tambang di Desa Tegallega

3. Kurangnya sarana dan prasarana pendidikan, karena mayoritas masyarakat Desa Tegallega hanya lulus pada tingkat pendidikan Sekolah Dasar (SD)

4. Kurangnya sarana prasarana mobilitas karena kondisi jalan di Desa Tegallega dalam keadaan rusak atau belum dibangun, selain itu belum terdapat lampu penerangan jalan dan belum terdapat pula rambu-rambu petunjuk jalan atau nama jalan/wilayah.

5. Kurangnya sarana prasarana sanitasi, karena di Desa Tegallega belum terdapat tempat penampungan sampah rumah tangga yang memadai dan di beberapa dusun masih banyak warga yang belum mempunyai mck sendiri.

6. Usaha Mikro Kecil Menengah (UMKM) di Desa Tegallega sangat minim atau bisa dikatakan belum ada

Dari hasil pengamatan observasi maupun identifikasi masalah keadaan masyarakat desa Tegallega diatas, maka sangat diperlukan upaya-upaya yang bersifat membangun untuk meningkatkan keadaan di desa Tegallega baik oleh kami mahasiswa KKN Kelompok 49-50 UIKA Bogor bersama warga yang bekerjasama dengan instasi terkait. Berikut beberapa langkah upaya-upaya yang dilakukan adalah :

1. Meningkatkan kualitas Sumber Daya Manusia masyarakat Desa Tegallega dengan meningkatkan pengetahuan maupun kemampuan masyarakat Desa Tegallega

2. Meningkatkat kesadaran masyarakat di Desa Tegallega akan pentingnya menjaga kebersihan

3. Meningkatkan sarana mobilitas di desa Tegallega dengan mendirikan rambu petunjuk arah di dua titik pertigaan

4. Serta memotivasi masyarakat untuk mandiri dengan menggali potensi keadaan yang ada di sekitar masyarakat Desa Tegallega. 


\section{Letak Geografis}

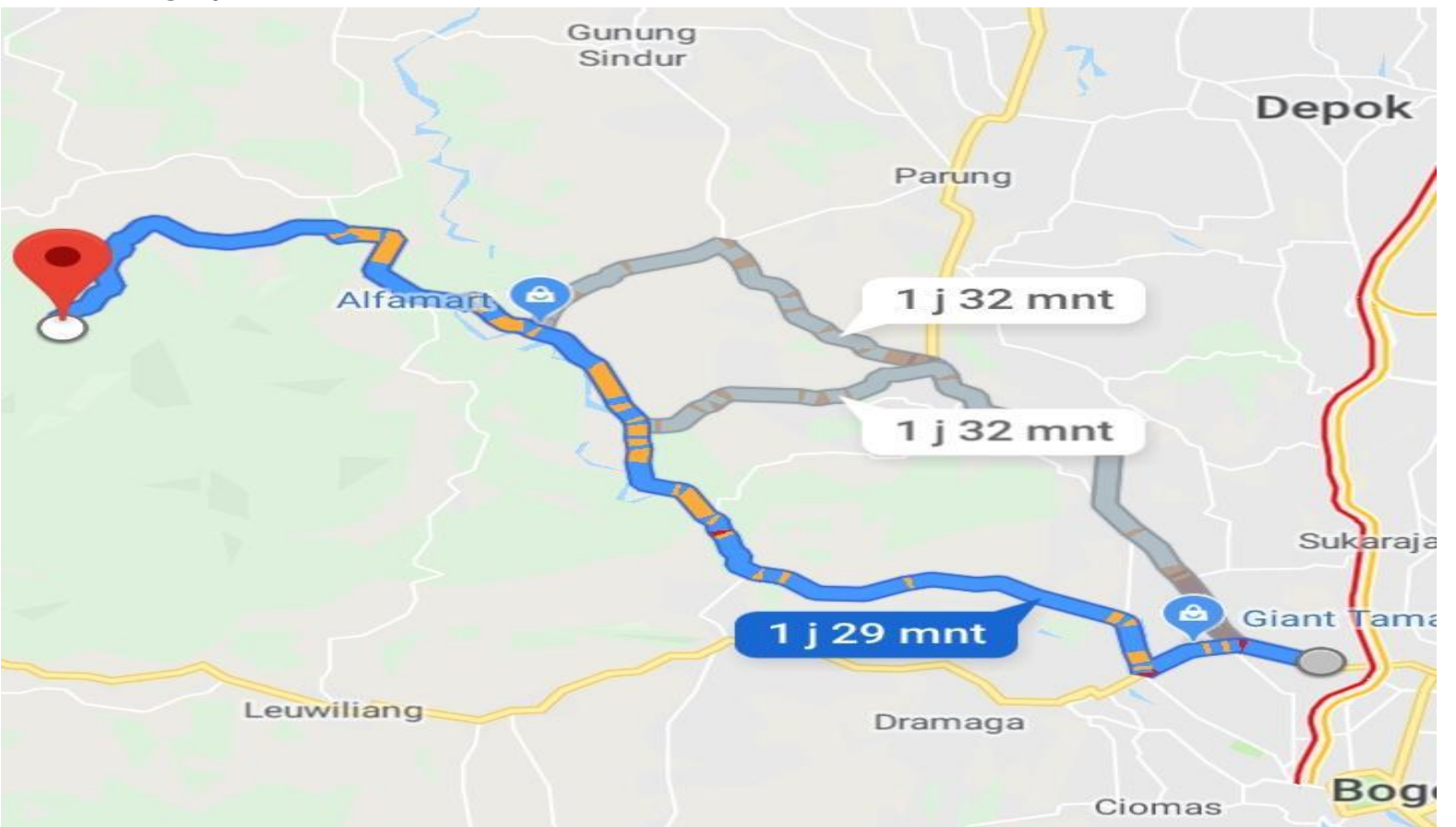

Desa Tegallega merupakan desa yang berada di daerah pegunungan diantara lahan pertanian dan kehutanan dengan ketinggian antara 108 - 250 M diatas permukaan laut. Sebagian besar wilayah Desa Tegallega adalah Perbukitan dengan kemiringan antara $35-75^{\circ}$ di sebelah timur dibatasi oleh Desa Cipinang Kecamatan Rumpin dan di sebelah selatan berbatasan dengan Desa Banyu Asih, disebelah barat berbatasan dengan Kecamatan Jasinga serta di sebelah selatan berbatasan dengan Provinsi Banten. Jarak desa Tegallega dengan Bogor Kota sekitar $42 \mathrm{~km}$ atau jika ditempuh menggunakan kendaraan dengan waktu 1 jam 45 menit.

\section{METODE}

\section{Tahap Pelaksanaan}

\begin{tabular}{|c|c|c|c|c|c|}
\hline \multirow[t]{2}{*}{ No } & \multirow[t]{2}{*}{ Kegiatan } & \multicolumn{3}{|c|}{ Agustus } & September \\
\hline & & Minggu 2 & Minggu 3 & Minggu 4 & Minggu 1 \\
\hline 1. & Survey Lokasi & & & & \\
\hline 2. & $\begin{array}{l}\text { Silaturahmi Tokoh dan } \\
\text { masyarakat }\end{array}$ & & & & \\
\hline 3. & Penyusunan progam kerja & & & & \\
\hline 4. & Sosialisasi kegiatan & & & & \\
\hline 5. & $\begin{array}{l}\text { Mengajar di SDN } \\
\text { Nunggaherang } 1 \& 2\end{array}$ & & & & \\
\hline 6. & Bimbel B.Arab & & & & \\
\hline 7. & Mengajar Ngaji & & & & \\
\hline 8. & Taman Baca & & & & \\
\hline 9. & Bimbel B. Inggris & & & & \\
\hline 10. & Lomba 17 Agustusan & & & & \\
\hline
\end{tabular}




\begin{tabular}{|c|l|l|l|l|l|}
\hline 11. & $\begin{array}{l}\text { Bersih-bersih masjid dan } \\
\text { majelis }\end{array}$ & & & \\
\hline 12. & $\begin{array}{l}\text { Penyuluhan menabung sejak } \\
\text { dini \& celengan kreatif }\end{array}$ & & & & \\
\hline 13. & $\begin{array}{l}\text { Penyuluhan (PHBS) mencuci } \\
\text { tangan \& menggunakan } \\
\text { masker }\end{array}$ & & & & \\
\hline 14. & Market Day & & & \\
\hline 15. & Pembuatan Plang jalan & & & & \\
\hline 16. & Pembuatan Tong sampah & & & & \\
\hline 17. & Education competiton & & & & \\
\hline 18. & Penutupan KKN & & & & \\
\hline
\end{tabular}

\section{Metode Pendekatan}

Dalam KKN Kelompok 49-50 ini kami menggunakan metode pendekatan sosial. Yang dimaksud dengan pendekatan sosial di sini adalah upaya dari Perguruan Tinggi, khususnya para mahasiswa peserta KKN selaku pelaksana utama dalam KKN untuk dapat mengintegrasikan diri (meleburkan diri) ke dalam berbagai kegiatan masyarakat agar dapat diterima dan berperan-serta dalam berbagai kegiatan masyarakat di tempat KKN.

Pendekatan sosial dilakukan dalam seluruh rangkaian pengelolan kegiatan KKN, baik pada tahap perencanaan, pelaksanaan, maupun pada tahap evaluasi. Dalam tahap perencanaan kami melibatkan pihak perangkat Dusun untuk sama-sama menyusun progam, kami berkonsultasi pula dengan masyarakat mengenai rencana progam-progam yang akan kami jalankan apakah masyarakat setuju atau tidak dan apakah progam kami menyalahi aspek yang berlaku didusun tersebut atau tidak, apalagi dalam tahap pelaksanaan kami mengajak langsung masyarakat untuk turut ikut serta dalam kegiatan-kegiatan yang kami susun karna pada dasarnya semua progam-progam yang kami susun sasaranya adalah masyarakat.

\section{Metode Pengabdian}

Metode pengabdian yang kami gunakan yaitu :

1. Metode bimbingan dan penyuluhan Pada metode ini guru/pemateri memberikan beberapa informasi ataupun materi kepada murid atau peserta melalui lisan dan dibantu dengan lagu dan video edukasi agar murid ataupun peserta tidak merasa bosan. Metode ini digunakan untuk progam kerja penyuluhan (PHBS) mencuci tangan dengan baik dan benar, penyuluhan menabung sejak dini dan celengan kreatif serta bimbel B.Inggris maupun bimbel B.Arab.

2. Metode coaching

Metode bimbingan, pengarahan, sekaligus pengawasan. Metode ini diawali dengan dibentuknya kelompok-kelompok lalu disetiap kelompok ada mentor. Mentor disini berugas memberi materi atau informasi, mengarahkan hal-hal apa aja yang harus kelompok lakukan, serta pengawasan kegiatan kelompok oleh mentor. Metode ini digunakan untuk progam kerja Market Day. 
Partisipasi Masyarakat Dalam

\section{Pelaksanaan Progam}

Sebuah kegiatan pengabdian masyarakat pasti melibatkan partisipasi dari masyarakat sekitar lokasi pengabdian, berikut adalah partisipasi dari masyarakat desa lokasi KKN :

1. Menyediakan tempat tinggal untuk menjadi posko KKN

2. Membantu mensosialisasikan kegiatan-kegiatan yang berada di posko ke warga-warga lain sehingga kegiatan-kegiatan diposko ramai peserta

3. Menyediakan tempat serta sarana prasarana yang mendukung proses pembuatan Plang petunjuk jalan dan tong sampah

4. Menyambut ramah ,membantu mempersiapkan, sekaligus menyediakan tempat \& mengkondisikan peserta kegiatan penyuluhan (PHBS) mencuci tangan dan menggunakan masker serta kegiatan penyuluhan menabung sejak dini \& celengan kreatif

5. Mengizinkan tim KKN kelompok 4950 untuk mengajar di lembaga pendidikan setempat

6. Turut serta dalam meramaikan kegiatan lomba 17 Agustusan

\section{REALISASI PROGAM KERJA}

1. Learn and Fun dalam pembelajaran Bahasa Inggris

Permainan adalah salah satu komponen terpenting di kelas EFL. mereka termasuk kegiatan yang memiliki tujuan dan peraturan sekaligus kesenangan menurut Hadfeld (1990; Quoted IN Deesri, 2002, p.1) dalam jurnal Prof Dr. Huseyin Uzunboylu, Assoc, Prof. Dr. Cigdem Hursen, Near East University tahun
7. Turut serta membantu persiapan sekaligus ikut berpartisipasi dalam kegiatan penutupan $\mathrm{KKN}$

\section{Langkah Evaluasi}

Berikut adalah langkah-langkah evaluasi yang kelompok kami lakukan :

1. Evaluasi proses

Adalah evaluasi mulai dari perencanaan, pelaksanaan, sampai dengan pengawasan kegiatan, evaluasi dilakukan diakhir berjalanya suatu progam kerja/ kegiatan

2. Evaluasi hasil

Adalah evaluasi yang dilaksanakan setelah semua rangkaian progam kerja/ kegiatan telah selesai dilaksanakan, evaluasi ini dilakukan untuk melihat sejauh mana perkembangan di Desa Tegallega sebelum dan sesudah berjalanya progam kerja dari kelompok KKN 49-50

3. Evaluasi dampak

Adalah evaluasi yang dilaksanakan setelah kegiatan KKN berakhir, nantinya kami berencana akan berkunjung kembali ke Desa Tegallega untuk melihat bagaimana evaluasi dampak yang dihasilkan setelah KKN berakhir, apakah progam yang coba kami jalankan masih dapat berjalan disana atau sebaliknya.

2016 yang berjudul The Importance Of Using Games IN EFL Classrooms

Learn and fun dalam pembelajaran B.Inggris ini merupakan salah satu progam dari fakultas Keguruan dan Ilmu Pengetahuan, progam ini adalah progam pembelajaran B.Inggris yang dikemas semenarik mungkin dengan menyisipkan permainan atau games ringan didalam pembelajaran bimbel 
tersebut. Sasaran dari kegiatan ini adalah anak-anak yang berada di sekitar posko KKN 49-50 dan siswa SD N 1 \& 2 Nunggaherang. Adapun hasil yang diperoleh yaitu :

Pertama anak-anak akan merasa senang dan termotivasi untuk belajar B.inggris, antusiasme anak-anak dalam belajar bahasa Inggris boleh dibilang sangat bagus, apalagi jika dalam proses belajar dibuat seasik mungkin dengan bantuan games ringan dan nyanyian agar mudah menghafal kosa kata dalam bahasa inggris, terlihat anak-anak sangat menikmati proses pembelajaran dan enggan untuk menyudahi proses pembelajran, selain itu setiap harinya peserta progam tersebut kian meningkat, dari sini terlihat bahwa progam pembelajaran bahasa inggris yang kami kemas dengan menarik ini dapat memotivasi anak-anak untuk belajar bahasa inggris.

Selain dapat memotivasi anakanak, progam ini juga telah meningkatkan kemampuan anak-anak dalam berbahasa inggris, sebelum adanya prgam ini kemampuan anakanak Desa Tegallega dalam bidang B.inggris bisa dibilang kurang atau tertinggal dibanding dengan anak-anak sebaya didaerah lain khususnya daerah kabupaten Bogor yang lain, tapi setelah kami adakan progam ini kemampuan anak-anak hampir seimbang atau sudah dapat menyamai kemampuan anakanak sebaya didaerah lain dalam hal berbahasa Inggris.

2. Education Competition

Education competition merupakan salah satu progam dari fakultas agama islam, dimana progam ini adalah progam evaluasi atas progam yang telah dilaksanakan sebelumnya seperti bimbel B. Arab. Sasaran progam ini adalah anak-anak yang mengikuti kegiatan bimbel B.Arab. Adapun hasil yang diperoleh yaitu :

Pertama mengukur sejauh mana keberhasilan progam kerja bimbel B.Arab, jadi hasil yang diperoleh dari kegiatan tersebut merupakan barometer keberhasilan dari progam bimbel B.Arab yang telah kami laksanakan, dan Alhamdulillah hasilnya sangat memuaskan, terbukti saat berjalanya progam ini kami sampai harus mencari soal tambahan karna semua soal yang kami siapkan mampu dijawab oleh peserta dengan baik dan benar.

Selanjutnya motivasi anak-anak dalam belajar bahasa asing khususnya B.Arab meningkat, setelah kegiatan ini peserta lomba menginginkan progam bimbel B.Arab terus berlanjut, tapi karna terbatasnya waktu pengabdian pada masyarakat ini dengan sangat disayangkan progam bimbel B.Arabpun tidak dapat berlanjut.

Selain dua hal diatas, progam ini juga mampu mengajarkan kepada anak-anak untuk bersaing dalam kebaikan (fastabiqul khoirot), karena progam ini berbasis competition atau pertandingan tentu saja dari berjalanya progam ini anak-anak diajarkan dan dilatih untuk bersaing sportif untuk menjadi pemenang. Yang terakhir anak-anak mampu menguasai dan menghafal kosa kata B.Arab.

3. Pembuatan Plang Petunjuk Jalan

Progam ini merupakan progam unggulan kelompok KKN 49-50 dimana dengan adanya progam ini tidak hanya masyarakat sekitar Desa Tegallega saja yang merasakan manfaatnya tapi juga semua orang yang berkunjung ke Desa Tegallega juga 
bisa turut merasakan kebermanfaat dari progam ini, salah satu progam dari fakultas teknik ini berada pada 2 titik lokasi pertigaan yang berada di Desa Tegallega, adapun hasil yang diperoleh yaitu :

Terdapat rambu-rambu petunjuk jalan di Desa Tegallega yang diharapkan mampu mempermudah para pendatang Desa Tegallega dalam mencari lokasi/wilayah didaerah Desa Tegallega

4. Penyuluhan (PHBS) mencuci tangan dengan baik dan benar

Riset Kesehatan Dasar (Riskesdas) 2007, perilaku cuci tangan masyarakat Indonesia masih rendah, dan anak usia sekolah dasar, baru $17 \%$ melakukan Cuci Tangan Pakai sabun dan air bersih dalam Jurnal Nasional Ilmu Kesehatan (JNIK) LP2M Unhas, Vol 1,2. 2018. Dan faktanya riset tersebut benar adanya di Desa Tegallega kesadaran msyarakat untuk mencuci tangan masih rendah.

Penyuluhan mencuci tangan dengan baik dan benar ini adalah kegitan edukasi langkah-langkah mencuci tangan dengan baik dan benar dengan menggunakan bantuan musik agar menarik dan mempermudah anakanak untuk menghafal langkahlangknya. Salah satu progam dari fakultas kesehatan ini dilaksanakan di dua tempat yaitu di SDN 1 Nunggaherang dan di posko KKN, adapun hasil yang diperoleh yaitu :

Meningkatkan kesadaran anakanak akan pentingnya perilaku hidup bersih dan sehat, sebelum diadakanya kegiatan penyuluhan ini kesadaran anak-anak akan pentingnya menjaga kebersihan sangatlah kurang, banyak ditemui di SD sebelum makan anak- anak enggan untuk cuci tangan bahkan setelah makanpun mereka tidak mencuci tanganya, setelah diadakanya penyuluhan ini sebagian anak-anak ada yang mulai sadar akan pentingnya mecuci tangan, di SD ada beberapa anak yang kita jumpai mencuci tanganya sebelum dan sesudah makan jajanan dengan urutan-urutan yang benar sesuai dengan yang kita ajarkan.

Dari pemaparan diatas dapat disimpulakn bahwa kini anak-anak sudah tahu cara mencuci tangan yang baik dan benar, selain itu anak-anak juga sudah tahu kapan-kapan saja harus mencuci tangan.

5. Market Day

Market day merupakan salah satu progam dari fakultas ekonomi dan bisnis dan prodi ekonomi syariah, market day merupakan progam yang bertujuan untuk menumbuhkan jiwa enterpreneursip pada anak-anak, menurut leonita dalam jurnalnya yang berjudul menanamkan nilai kewirausahaan dalam kegiatan market day menyatakan bahwa Kewirausahaan ini merupakan sikap mental dan jiwa yang selalu aktif dan kreatif, dan berusaha dalam rangka meningkatkan pendapatan atas kegiatan usahanya. Ada 6 nilai pokok kewirausahaan yang dapat diintegrasikan dalam pembelajaran pada anak usia dini, yaitu: mandiri, kreatif, pengambil risiko, kepemimpinan, orientasi ada tindakan, dan kerja keras. progam ini dilaksanakan di SDN 2 Nunggaherang dengan peserta market day siswa kelas 5 dan 6, sedangkan konsumen atau pembelinya adalah seluruh warga sekolah, termasuk orangtua/wali murid. Adapun hasil yang diperoleh yaitu : 
Anak-anak mulai termotivasi menjadi entrepreneur terbukti jika sebelum kegiatan ini jika ditanya citacita mereka tidak ada yang ingin menjadi entrepreneur setelah kegiatan ini banyak anak-anak yang ingin menjadi entrepreneur

Selain itu Market Day mampu merangsang kreatifitas anak-anak untuk mengolah sesuatu agar dapat bernilai ekonomi lebih, seperti yang sudah kami paparkan diatas bahwasanya di Desa Tegallega tidak didapati UMKM dan sesuai dengan tema KKN kami, kami ingin mewujudkan desa Tegallega yang mandiri, oleh karnanya melalui progam ini kami mencoba untuk meningkatkan kreatifitas masyarakat melalui pengolahan barang atau bahan yang ada di sekitar masyarakat, dalam

\section{PENUTUP}

\section{Kesimpulan}

Berdasarkan pemaparan di atas, dapat dikatakan bahwa pengabdian mahasiswa KKN 49-50 di Desa Tegallega, Kecamatan Cigudeg mendapatakan respon positif dari masyarakat. Ada 5 dari 13 program kelompok yang dilaksanakan kelompok KKN 49-50 di Desa Tegallega. Dengan rincian : 1 program fisik, 4 program nonfisik. Program fisik terdiri dari plangisasi atau plang petunjut jalan, sedangkan program non-fisik meliputi learn and fun dalam pembelajaran B.Inggris, Education Competition, penyuluhan (PHBS) mencuci tangan dengan baik dan benar, serta Market Day.

Dalam pelaksanaan program di atas, ada beberapa faktor yang mendukung dan/atau menghambat pelakasanaanya. Adapun faktor yang mendukung meliputi dukungan masyarakat seperti dukungan progam ini barang yang kami buat dan pasarkan berbahan dasar makanan seperti pisang, melon, jelly, sosis \& mie telor yang sudah kami pastikan semua bahan dasar tersebut mudah ditemui di Desa Tegallega, kemudian bahan-bahan dasar diatas kami kreasikan dan olah menjadi makanan yang lebih menarik seperti pisang susu keju, es kulkul melon berbalut cokelat, rainbow jelly, dan sosis mie goreng yang belum ada di Desa Tegallega. Respon konsumenpun baik dari dimulainya proses pemasaran tidak membutuhkan waktu lama untuk menjual semua barang dagangan.

Disamping itu market day juga dapat membantu anak-anak untuk mendapatkan tambahan uang saku dari laba market day.

tenaga, atau sikap membutuhkan akan program yang dijalankan. Adapun faktor penghambat meliputi keterbatasan waktu dan kurang matangnya konsep beberapa progam yang menyebabkan beberapa pelaksanaan program belum maksimal. Terlepas dari faktor-faktor tersebut, seluruh program KKN yang telah direncanakan sebelumnya telah tercapai $100 \%$ dalam pelaksanaanya. Sebagian besar program disambut positif oleh masyarakat Desa Tegallega yang dibuktikan dengan partisipasi warga yang aktif. Setiap program yang diadakan oleh tim KKN 49-50 selalu dihadiri oleh masyarakat khususnya anakanak Desa Tegallega, mereka mengikuti program dengan sangat antusias. Kedepannya, diharapkan program-program yang telah terlaksana seperti learn and fun dalam pembelajaran B.Inggris dan taman baca dapat diteruskan oleh pihak dusun 
sehingga program yang telah dijalankan tim KKN 49-50 tidak berhenti seiring dengan berhentinya KKN di Desa Tegallega.

\section{Saran}

Sebagai upaya revitalisasi disegala bidang yang relevan dengan KKN, maka kami perlu mengemukakan beberapa saran yag sifatnya membangun, adapun sarannya antara lain :

1. Untuk tim LPPM UIKA Bogor kami berharap untuk tahun depan progam KKN dapat dilaksanakan kembali dan dapat lebih dioptimalkan, dengan diterjunkan langsung dalam masyarakat yang benar-benar belum bisa baca dan tulis (buta aksara), yang kebanyakan adalah masyarakat ekonomi rendah

2. Untuk pengemban kebijakan di tingkat Desa, Kecamatan, dan Kabupaten kami berharap lebih dapat memperhatikan lagi perkembangan Desa Tegallega, dan dapat meningkatkan lagi mutu pendidikan di Desa Tegallega serta mampu meningkatkan sarana prasarana pendukung seperti jalan, kontruksi, fasilitas kesehatan, fasilitas umum, listrik, dan ketersediaan air bersih, terutama jalan beserta sarana prasarana pendukungnya karena memang keadaan jalan dan sarana prasarana pendukung di daerah Desa Tegallega sangat memprihatinkan

3. Untuk masyarakat Desa Tegallega khususnya Dusun Binong, kami berharap dapat terus menjaga tali silaturahmi, rasa persaudaraan, kerjasama, serta rasa gotong royong. Selain itu kami berharap dari terlaksananya progam-progam $\mathrm{KKN}$ tingkat kesadaran masyarakat Dusun Binong akan pentingnya pendidikan bertambah, orang tua juga kami harapkan dapat menjaga semangat belajar anak-anaknya agar tidak hanya semangat saat proses KKN berlangsung saja namun juga semangatnya tetap terjaga setelah kegiatan KKN berakhir

4. Kamipun berharap kader-kader taman baca dan bimbel yang telah kami beri amanah untuk meneruskan mampu meneruskan progam-progam yang telah kami rintis, serta dapat menerapkan konsep pelaksanaan kegiatan, sebagaimana yang telah dilakukan oleh mahasiswa KKN

5. Untuk perangkat Desa setempat, kami berharap di tahun-tahun berikutnya bisa lebih perhatian terhadap Mahasiswa KKN serta bisa lebih aktif dalam berpartisipasi di kegiatankegiatan Mahasiswa KKN yang memang berkaitan dengan pihak desa. 


\section{REFERENSI}

Leonita Siwiyanti Suharyoto.2017. Jurnal Menanamkan Nilai Kewirausahaan Dalam Kegiatan Market Day

Prof Dr. Huseyin Uzunboylu, Assoc, Prof. Dr. Cigdem Hursen, Near East University. 2016. Jurnal The Importance Of Using Games IN EFL Classrooms

Muh Fajaruddin Natsir. 2018.Jurnal Pengaruh Penyuluhan CTPS Terhadap Peningkatan Pengetahuan Siswa SDN 169 Bonto Parang Kabupaten Jeneponto

Vika Fatimatuz Zahro, M. Fachreza Afdi. 2017. Jurnal 30 hari Gaungkan Tegallega http://kecamatancigudeg.bogorkab.go.id/

http://www.bogorkab.go.id/

https://docplayer.info/54899797-Editoramalia-se-msm-penulis-vikafatimatuz-zahro-m-fachrezaafdi.html

https://akhmadsudrajat.wordpress.com/200 8/02/14/pendekatan-sosial-dalamkegiatan-kkn/

https://ejournal.unisba.ac.id/index.php/gold en_age/article/view/2861

http://afsirmlajah.blogspot.com/2017/04/

http://eprints.uad.ac.id/6269/6/BAB\%20V. pdf 